\title{
Ecosystem service trade-offs upstream and downstream of a dam: a case study of the Danjiangkou dam, China
}

\author{
Hai Liu ${ }^{1,2,3} \cdot$ Jing Wu ${ }^{2} \cdot$ Mingwei Liao ${ }^{3}$
}

Received: 2 September 2018 / Accepted: 30 November 2018 / Published online: 4 January 2019

(C) The Author(s) 2019

\begin{abstract}
Studying the trade-offs and synergies between ecosystem services upstream and downstream of dams is of great importance because such studies can help guide the coordinated development of ecosystems. Taking the Danjiangkou dam as an example, we studied the trade-offs and synergies of ecosystem services in the river basin upstream and downstream of the dam. First, based on Costanza's research method, we used the equivalent factor method to revise the equivalent factor of the Hanjiang River Basin. This basin includes the Danjiangkou dam, which provides services for agriculture. On that basis, the spatio-temporal dynamics of ecosystem service values during the period of 1990-2015 for the whole basin were estimated. The relationships among ecosystem services upstream and downstream of the Danjiangkou dam and throughout the basin were then analyzed using correlation analysis. The results demonstrate that the value of ecosystem services for the entire basin steadily increased during the period of 1990-2015. Among all ecosystem services, climate regulation and hydrologic regulation presented the highest ecosystem service values. Clear differences in spatial patterns existed in the two analysis areas. The ecosystem service values upstream of the dam were higher than those downstream of the dam. Approximately $60 \%$ of the relationships among the ecosystem services in the whole basin were synergistic, which was the dominant relationship. Synergies were more common upstream of the dam than downstream, and these synergies existed primarily between regulation services and composite services and between regulation services and cultural services. Trade-offs were more common downstream of the dam and existed mainly between supply and regulation services. Upstream food production was involved in significant trade-offs with biodiversity below the dam. Raw material production, gas regulation, climate regulation, soil conservation, and biodiversity above the dam showed significant synergies with gas regulation and climate regulation downstream.
\end{abstract}

Keywords Ecosystem services · Upstream and downstream of a dam · Trade-offs and synergies · Danjiangkou

\section{Introduction}

Ecosystem services are benefits obtained directly or indirectly from ecosystems (Wilson and Matthews 1970; Daily 1997a; Costanza et al. 1997) and are closely linked to human wellbeing. With the increase in population and overexploitation of resources, services have been severely damaged (Daily 1997b). People have gradually realized that human activities and

Mingwei Liao

liaomingwei_2002@163.com

1 School of remote Sensing and information, Wuhan University, Wuhan 430079, Hubei, China

2 Faculty of Resources and Environmental Science, Hubei University, Wuhan 430062, Hubei, China

3 Jiangxi Provincial Geomatics Center, Nanchang 330209, Jiangxi, China government policies are changing the land use pattern and the spatial distribution of resources. These changes have changed the capabilities of ecosystem services through the influence of the ecosystem patterns and processes (Maes et al. 2012). As the core focus of ecosystem assessment, relationships between ecosystem services have recently gained increasing attention in the scientific community (Sandifer et al. 2015; Brown and Fagerholm 2015). The United Nations conducted the first comprehensive assessment of global ecosystem services. In 2005, the Millennium Ecosystem Assessment (MA, http://www. millenniumassessment) was completed. Many different actors have advocated for consideration of ecosystem services in different areas (Sutherland et al. 2006; Langner et al. 2017).

There has been an increased interest in translating the provision of basin-scale ecosystem services to a wider variety of benefits. With the MA work completed in 2005 (MA 2005), the study of basin-scale ecosystem services has focused on the influence of ecosystem services on human well-being (Villasante 
et al. 2015; Li et al. 2011a, b; Gao et al. 2016). The fields to which ecosystem services have been applied have expanded gradually and now include resource and environmental management and regional planning (Schmalz et al. 2016).

With the increase in population and over-urbanization (Worm et al. 2006), the demands for ecosystem services by human activity far outstrip the available ecosystem services, which are the capacity of ecosystems to sequester pollutants and provide required natural goods (Guan et al. 2016b; Kai and Fan 2017). However, the demands for ecosystem services are not decreasing. Thus, to meet the growing demands, natural resources are being overly exploited and utilized by humans, and the capacities of basin ecosystems have been exceeded, resulting in a focus on ecosystem service needs at the expense of other services. Trade-offs among ecosystem services made it difficult to achieve maximum benefits simultaneously (Heina et al. 2006). For example, people want to obtain higher grain yields, and agricultural lands are constantly expanding, which results in losses of habitats and biodiversity (Alcamo et al. 2005). With the establishment of a dam, a large amount of water is blocked in the upstream section, which reduces the capacity of replenishing wetlands in the downstream section. If the wetlands cannot be suitably replenished, the ecosystem services of hydrological adjustment are weakened. The vegetation around the river decreases, and the related ecosystem services, such as gas regulation and climate regulation, also decrease. Additionally, spatial differences among ecosystem structures and processes control the spatial heterogeneity of ecosystem services (Kremen 2008). Demands for the types and quantities of ecosystem services differ, and therefore, the corresponding ecosystem service management strategies differ; this relationship makes it difficult to maximize the benefits of ecosystem services and achieve the coordinated development of ecosystem services in different regions of a basin (Raudsepphearne et al. 2010). For example, upstream and downstream demands for irrigation, aquaculture production, and water purification differ (Schlüter et al. 2009). The diversion of water from a river to a town for domestic water or for irrigation water to an agricultural area will leave people living downstream without sufficient water to meet their needs. The use of water upstream imposes an externality on those living lower in the basin. Therefore, it is necessary to study the relationships among ecosystem services to achieve the coordinated development of the different ecosystem services in different regions, to achieve the maximum benefits for stakeholders and optimize the management of ecosystem services (Daily et al. 2009), and to reach win-win goals for regional development and ecological protection (Cao et al. 2016; Li et al. 2017).

Trade-offs occur when one ecosystem service is reduced as a consequence of increased use of another ecosystem service. Synergism means that one ecosystem service is enhanced or reduced simultaneously with another ecosystem service (Raudsepphearne et al. 2010; Agarwala et al. 2014). The interactions among ecosystem services can be influenced by the demands of stakeholders at different scales (temporal and spatial). Almost all decision-making about ecosystem services involves the balancing of interests (Rodríguez et al. 2006). Tradeoffs and synergies therefore exist in ecosystems worldwide, with significant regional differences and dynamic changes.

At present, evaluations of ecosystem services can be roughly divided into two types: the method of ecosystem service value based on a unit function price (hereafter referred to as the functional value method) and the method of ecosystem service value based on a unit area (hereafter referred to as the equivalent factor method). Compared with the functional value method, the equivalent factor method is more intuitive and easily applied and poses fewer data demands. Costanza used the latter method to evaluate ecosystem service values worldwide in 1997. The method was then widely used to evaluate ecosystem services at global and regional scales. Therefore, in this study, we evaluated the value of ecosystem services in the Hanjiang River Basin using the equivalent factor method. Currently, studies are focused on the identification of trade-offs and synergies in ecosystem services (MA 2005; Cord et al. 2017). Most of these studies have been qualitative analyses (Sun and Li 2017). The research methods have consisted mainly of geography and ecological theory, as represented by the integrated ecological-economic modeling framework (Byron et al. 2015). The model is a combination of several ecological models and socio-economic evaluation models. Ecological models are used to describe changes in ecosystem services, and socio-economic evaluation models reflect the impacts of ecological changes on human well-being (Higgins et al. 1997; Chisholm 2010; Hussain and Tschirhart 2013; Posnera et al. 2016). In general, the latter model is sufficiently mature and widely used. However, this method is often used to analyze the trade-offs between market-oriented ecosystem services and has a clear disadvantage when applied to trade-offs between ecosystem services consisting of public goods because it is hard to calculate these ecosystem services by this method. In addition, the method requires a large amount of research data and is usually used on smaller research scales (Farber et al. 2006). That method is based on land use data in combination with relevant eco-economic policies to simulate multiple scenarios and to understand the trade-offs and synergies of various scenarios (Li et al. 2017; Alcamo et al. 2005; Trodahl et al. 2017). Because of difficulty in data acquisition and index construction, these two methods are not widely applied. In addition, the number of selected ecosystem services tends to be insufficient, and quantifications and assessments of the dynamic relationships between the overall benefits of ecosystem services and a single ecosystem service are rare. The interactions between ecosystem services are mainly one-way or bidirectional, and there have been few multidirectional competition analyses ( $\mathrm{Li}$ et al. 2012). In studies of typical areas, most current research is aimed at the relationships between ecosystem services provided by a particular basin or ecosystem (Liu et al. 2017; Kharrazi et al. 2016; Hurford and Harou 2014). However, these studies ignore the 
differences between trade-offs in the upstream and downstream parts of a basin in terms of spatial inconsistencies in the supply and demand of ecosystem services among various stakeholders (Bohensky et al. 2006).

Dam construction is a conscious human practice that changes the ecosystem services of basins, and dams are among the most influential features in basins affected by government policy. By the end of the twentieth century, 45,000 dams had been built throughout the world (WCD 2000). On the one hand, dams, which are an important aspect of human civilization, play an important role in socio-economic development, particularly flood control and irrigation (Lu et al. 2003). On the other hand, dams have a profound impact on ecosystem structures, functions, and services in basins via regulation of basin water resources, which in turn affects basin water resources, soil, climate, and biodiversity (Zhao and Zhang 2006). Therefore, studying the impact of dams on ecosystem services upstream and downstream of dams will aid in the understanding of the environmental effects generated by large-scale water conservation projects and thus provide a scientific basis for protecting the integrity of the structures and functions of basins and for the sustainable development of engineering projects and regional development. At present, related research on dams has concentrated mainly on rivers and nearby areas (Bonacci and Bonacci 2003). Only Ziv Guy has undertaken a comparative analysis of the trade-offs among ecosystem services before and after the construction of dams in the Mekong River Basin (Ziv Guy et al. 2012).

In the 1970s, to alleviate the shortage of water resources in the north, the Chinese government decided to implement the Middle Route of the South to North Water Transfer Project and chose the Danjiangkou area as the water source for this project. Construction work of the Danjiangkou dam began in 1973. It is located at the confluence of the Hanjiang River and its tributary, the Danjiang River, in China. It is a large-scale water control project that serves mainly for water diversion and flood control, and the project involves a comprehensive combination of power generation, irrigation, shipping, and aquaculture. It is not only the key project for harnessing the Hanjiang Rivers but is also an important part of the middle line project of the Middle Route of the South to North Water Transfer Project in China (Zhou et al. 2015). After a half century of construction, the Middle Route project was completed in December 2014. The area upstream of the Danjingkou dam is the source of water for the Middle Route project, and the area downstream of the dam is affected by the Middle Route project. It is important to analyze the trade-offs and synergies among ecosystem services upstream and downstream of the dam to analyze the effects of the Middle Route Project on the ecological environment in the Hanjiang River Basin, to determine the ecological and economic impacts of the dam, such as on food production and water supply, throughout the basin and to develop scientific recommendations for water diversions. At present, studies of ecosystem services upstream and downstream of the Danjiangkou dam have focused on the evaluation of services such as soil and water conservation in farmlands, forests, and wetlands (Zhang et al. 2017; Chen et al. 2016) and on simulations of ecosystem service changes based on land use data ( $\mathrm{Li}$ et al. 2011a, b; Chen et al. 2015). In terms of trade-offs and synergies among ecosystem services, few studies have been conducted in which areas upstream and downstream of the Danjiangkou dam were compared.

Therefore, in this study, we used an approach similar to that used by Costanza to obtain ecosystem service value during 1990-2015 both upstream and downstream of the Danjiangkou dam in order to analyze the dynamic changes and differences in ecosystem services from the perspectives of time and space. On that basis, ecosystem service values were further revised taking into account the spatial characteristics of the whole basin. The trade-offs and synergies among ecosystem services were analyzed via correlation analysis from three aspects: the whole basin, the areas upstream and downstream of the dam taken separately, and the combination of the areas upstream and the downstream of the dam. Ten ecosystem services were selected for this study. The trade-offs and synergies among these ecosystem services in the whole basin were comprehensively analyzed. The relationships among the overall benefit from all the ecosystem services and the benefits of the individual ecosystem services were analyzed. The role of a single ecosystem service in the overall benefit became clear, and the dominant ecosystem services in the basin were thus easier to identify. In addition, this study contributes to providing direction and support for the sustainable growth of ecosystem services throughout the basin. This paper presented a comprehensive analysis of the trade-offs and synergies among ecosystem services from three aspects, considering that demands for the types and quantities of ecosystem services differ among various stakeholders. Based on the analysis of the trade-offs and synergies in the areas upstream and downstream of the dam, the research clearly shows that the spatial differences and contact interactions between these two areas are useful for analyzing the influence of the dam on the ecosystem services upstream and downstream and provide a reference for the coordinated development of the areas upstream and downstream of the dam.

\section{Data and methods}

\section{Data}

The Hanjiang River is located in central China. It is the longest tributary of the Yangtze River and has a total watercourse length of $1577 \mathrm{~km}$ and a drainage area of 15,900,000 ha. The Hanjiang River Basin is surrounded by mountains on three sides, and the Jianghan Plain is located in the southeast part of the basin. The Hanjiang River flows through the 
provinces of Shanxi, Hubei, and Henan in China, which are located in a subtropical monsoon climate zone. Based on the local conditions and the impact of the Danjiangkou dam on the basin, the area upstream of the Danjiangkou dam was designated the upper part of the river basin and measures $9,520,000$ ha in area. The area downstream of the Danjiangkou dam was designated the lower part of the river basin and measures 6,380,000 ha. The average annual precipitation in the upper part of the river basin is $923 \mathrm{~mm}$, which has significant transitional climate characteristics. There are many rivers in the upper part of the river basin. The vegetation is mainly subtropical evergreen broad-leaved forest. Due to the large latitude and longitude gradient and the difference in altitude, the spatial heterogeneity of environmental factors in the water source area is complex, and the biodiversity is extremely rich. The production activities are mainly based on agriculture, and the level of economic development is generally low. The land use type is mainly forestland and grassland. The average annual precipitation the lower part of the river basin is $853 \mathrm{~mm}$, and the terrain is in the southeast and northwest. The altitude gradually decreases from west to east, and the vegetation types are mainly subtropical evergreen broadleaved forests. The population in the basin is about 3 million. Compared with the upper part of the river basin, the level of economic development is relatively high, and the land use type is mainly agricultural land and forestland (Fig. 1).

The main data used in this study include six periods of land use data (1990-2015) that were provided by the National Earth System Science Data Sharing Infrastructure (http://www.geodata.cn). The sown area and the incomes and expenditures per unit area for rice, wheat, and corn were obtained from the Statistical Yearbook of China. The yields per unit area of farmland in Shanxi, Hubei, and Henan Provinces were obtained from the Statistical Yearbooks of the corresponding provinces.

\section{Methods}

\section{Methods for quantifying ecosystem services}

We calculated the equivalent factor of one standard unit first, and ecosystem service equivalent values per unit area for different land use types in 2010 were calculated with reference to the ecosystem service equivalent value per unit area in China proposed by Xie (Xie et al. 2008, 2015a, b). The equivalent factor was then further revised for different periods and provinces based on grain yields from the Statistical Yearbook of China. Finally, the ecosystem service value in the Hanjiang River Basin was calculated using an ecosystem service value estimation model.

Classification of ecosystem services This classification of ecosystem services in this study is based on that of the MA. Four types of ecosystem services are selected: supply services, regulation services, composite services, and cultural services. The reasons are as follows, supply services can provide direct commodities for human beings through primary production and secondary production or parts that may form commodities in the future, such as food, industrial raw materials, medicines, and other products necessary for human beings. Among the supply services, besides food production and raw material production, the current situation of the poor water resources
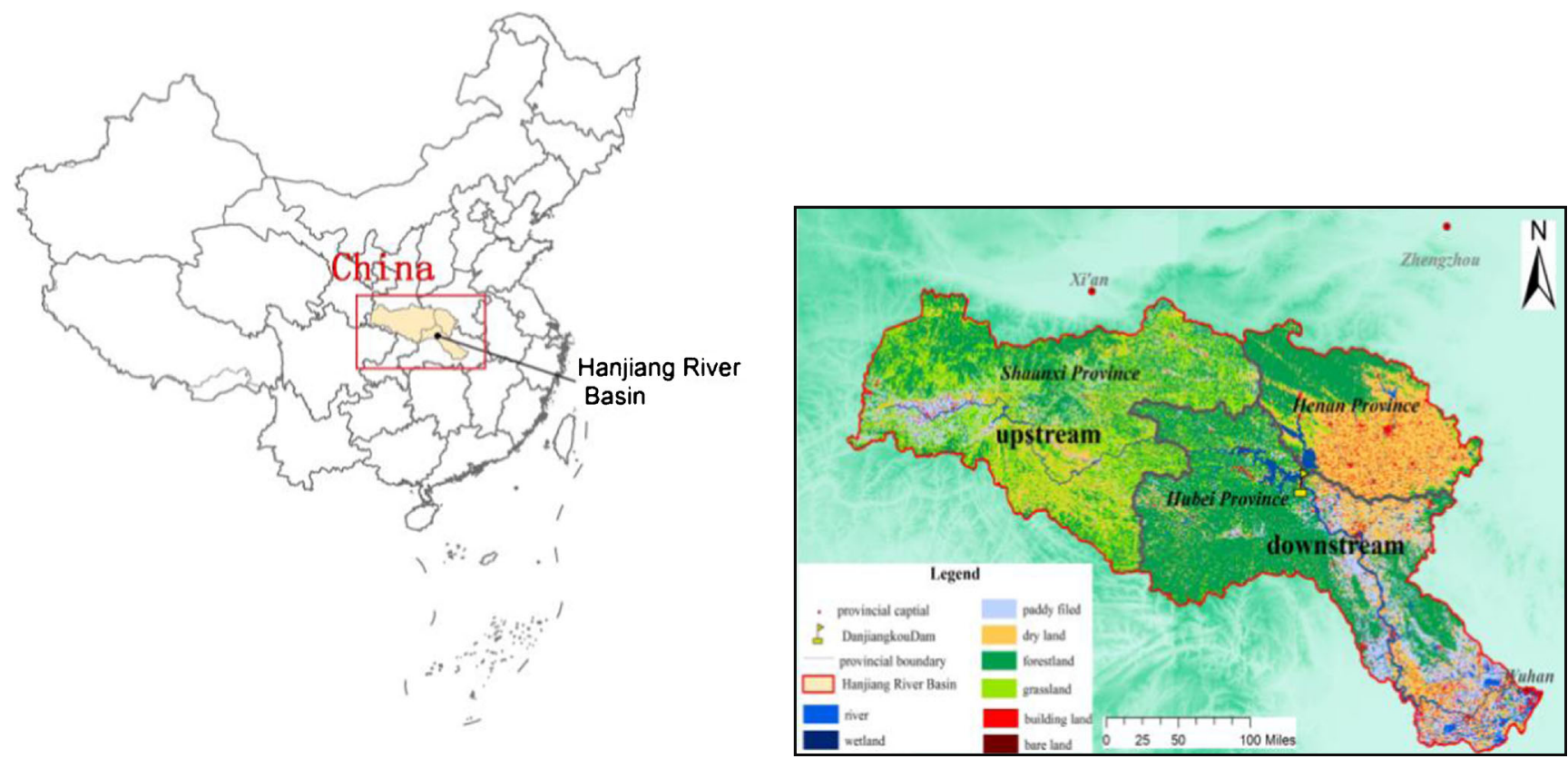

Fig. 1 Location of the Hanjiang River Basin 
in China has made water supply very important, so it is included in the classification separately. Regulation service is the function of supporting and maintaining human living environment and life support system, such as climate regulation and gas regulation. Composite services are indispensable for the production of other ecosystem services; in this part, we choose soil conservation and biodiversity. Cultural services can provide entertainment and aesthetic enjoyment for human beings. Table 1 shows the classification of ecosystem services and the definition/use of each service based on the MA and the research results of Xie (Xie et al. 2015a, b).

\section{Estimation of ecosystem service value standard equivalent} factors The ecosystem service value standard equivalent factor (hereinafter referred to as the equivalent factor) is the economic value of a natural grain yield per year (Xie et al. 2003). On that basis, the value of the equivalent factor of other ecosystem services can be determined by combining expert knowledge, which can serve to characterize and quantify the potential contributions of various ecosystem services. In this study, the net profit from food production of a farmland ecosystem per unit area was used as the ecosystem service value of the standard equivalent factor developed by Xie (Xie et al. 2008). The formula for calculating this value is

$D_{\mathrm{j}}=\sum_{\mathrm{i}=1}^{\mathrm{n}} s_{\mathrm{ij}} w_{\mathrm{ij}}-p_{\mathrm{ij}}$

$D$ is the ecosystem service value (yuan/ha) of the standard equivalent factor, $S_{\mathrm{ij}}$ is the area (ha) of the $i$ th crop of the $j$ th year in the study area, $w_{\mathrm{ij}}$ is the total income per unit area of the $i$ th crop in the $j$ th year, and $p_{\mathrm{ij}}$ is the total expenditure of the $i$ th crop in the $j$ th year.

Using Eq. 1, the standard unit equivalent factor for China in 2010 was 48,119 yuan/ha.

Ecosystem service equivalent value per unit area The ecosystem service equivalent value per unit area is the basis for assessing the ecosystem service value of a regional ecosystem. It refers to the average annual equivalent value in different ecosystems per unit area and is the basis of the dynamic equivalent table, which represents the regional spatial differences and temporal changes in an ecosystem service value (Xie et al. $2015 \mathrm{a}, \mathrm{b})$. The ecosystem service value estimation model proposed by Costanza is widely applied in assessments of ecosystem services value in various ecosystems and countries.
Table 1 Classification of ecosystem services

\begin{tabular}{|c|c|c|}
\hline \multicolumn{2}{|c|}{ Classification of ecosystems } & \multirow{2}{*}{$\begin{array}{l}\text { Definition/use of the services } \\
\text { Food products from plants, animals, and microorganisms }\end{array}$} \\
\hline Supply & Food production & \\
\hline service & Raw production & $\begin{array}{l}\text { Raw production (for example, wood, jute, hemp, silk, and } \\
\text { other products) from plants, animals, and microorganisms }\end{array}$ \\
\hline & Water supply & $\begin{array}{l}\text { Refers to the water resources provided by ecosystems and used for } \\
\text { residential life, agriculture (irrigation), and industrial processes }\end{array}$ \\
\hline \multirow[t]{4}{*}{$\begin{array}{l}\text { Regulation } \\
\text { service }\end{array}$} & Gas regulation & $\begin{array}{l}\text { Ecosystems release chemicals into the atmosphere and also absorb } \\
\text { chemicals from the atmosphere, which can have a multifaceted } \\
\text { effect on gas }\end{array}$ \\
\hline & Climate regulation & $\begin{array}{l}\text { The ecosystem has an impact on both the local climate and the } \\
\text { global climate. For example, on the local scale, the change of land } \\
\text { use can affect the temperature and precipitation. On the global } \\
\text { scale, ecosystems play an important role in the climate through } \\
\text { the absorption and emission of greenhouse gases }\end{array}$ \\
\hline & $\begin{array}{l}\text { Hydrological } \\
\text { adjustment }\end{array}$ & $\begin{array}{l}\text { The timing and size of runoff, floods, and recharge of aquifers are } \\
\text { strongly influenced by changes in land cover, especially activities } \\
\text { that alter the water storage potential of the system, such as the } \\
\text { conversion of wetlands or the conversion of forests to farmland } \\
\text { or farmland to city }\end{array}$ \\
\hline & $\begin{array}{r}\text { Environment } \\
\text { depuration }\end{array}$ & $\begin{array}{l}\text { Vegetation and organisms in ecosystems to degrade excess nutrients } \\
\text { and compounds, retention of dust, decontamination, and other } \\
\text { functions }\end{array}$ \\
\hline \multirow[t]{2}{*}{$\begin{array}{c}\text { Composite } \\
\text { service }\end{array}$} & Soil conservation & $\begin{array}{l}\text { Accumulation of organic matter and vegetation root substances and } \\
\text { organisms in ecosystems to promote the formation and } \\
\text { conservation of soil }\end{array}$ \\
\hline & Biodiversity & The source and evolution of wild plant and animals and habitats \\
\hline $\begin{array}{l}\text { Cultural } \\
\text { service }\end{array}$ & $\begin{array}{l}\text { Aesthetic } \\
\text { landscape }\end{array}$ & $\begin{array}{l}\text { People can find aesthetic value in many aspects of ecosystems, } \\
\text { which is already reflected in their love of parks, boulevards, } \\
\text { and the choice of housing location }\end{array}$ \\
\hline
\end{tabular}


However, there are differences between global and Chinese ecosystems. Therefore, our results are biased in some respects toward conditions in China, including lower valuations of agricultural lands and higher valuations of wetlands (Xie et al. 2008, 2015a, b). For that reason, Xie Gaidi and colleagues, of the Institute of Geographic Science and Natural Resources Research CAS, revised the ecosystem service equivalent value per unit area based on a questionnaire survey of 700 professional personnel with ecology backgrounds and according to China's ecological systems and social-economic development (Xie et al. 2008, 2015a,b).

Because the classification of the land use data and the ecosystem classification standards of the Xie Gao team are different, it is necessary to reclassify the land use data according to the needs of this study.

In addition to the first level classification, there are differences between the second-level classifications, primarily involving forests and grasslands. In this study, forests were divided into woodlands, open forest, other forest, and shrub forest. In the study by Xie, however, forests were divided into coniferous forests, theropencedrymion forests, broad-leaved forests, and shrub forests. Considering that the Hanjiang River Basin is located in a subtropical monsoon climate zone, we merged woodlands, open forest, other forest, and shrub forest in forest lands into a broadleaved forest class, and we subdivided grasslands into high-coverage grasslands, moderate-coverage grasslands, and low-coverage grasslands. In the study by Xie, however, grasslands were divided into prairies, scrub-grasslands, and meadows. However, current research does not specify the equivalent factors of high-coverage grasslands, moderate-coverage grasslands, and low-coverage grasslands. In this study, therefore, these three types of grasslands were merged into the shrub class, considering the later calculation. After this reclassification, the ecosystem service equivalent value per unit area of the Hanjiang River Basin was obtained (Table 2).
Modification of equivalent factors Table 2 was obtained from Xie (Xie et al. 2015a, b) based on relevant data for China in 2010. Considering the spatio-temporal dynamics of ecosystem services, we revised the equivalent factors for 1990 2015 in the provinces of the Hanjiang River Basin based on the 2010 data. The specific steps were as follows.

First, the ecosystem service value of the standard equivalent factor was calculated for 2010. The equivalent factors for the 1990-2015 period were then revised based on the ratios of the corresponding yield per unit area of farmland to the yield per unit area of farmland in 2010. Finally, the equivalent factors for Shaanxi, Hubei, and Henan Provinces were revised based on the ratios of the yields per unit area of farmland in these respective provinces to the yield per unit area of farmland in China, with the following formula:

$D_{\text {ia }}=\left(P_{\text {iag }} / P_{\text {ig }}\right) * D_{\mathrm{i}}$

$D_{\text {ia }}$ is the equivalent factor of different provinces in different periods, $P_{\text {iag }}$ is the grain yield of different provinces in different periods, $P_{\text {ig }}$ is the grain yield of all of China in different periods, and $D_{\mathrm{i}}$ is the equivalent factor of all of China in different periods.

The revised results are shown in Table 3.

Model for estimation of ecosystem service values The ecosystem service equivalent values of various land use types per unit area from 1990 to 2015 for Shaanxi Province, Hubei Province, and Henan Province were calculated by combining Tables 2 and 3. On that basis, the land use data of multiple years for the Hanjiang River Basin were taken as the main data source, and the ecosystem service value of the Hanjiang River Basin was estimated using the ecosystem service value estimation model. This model consists of the equations

$$
\begin{aligned}
& \mathrm{VC}_{\mathrm{i}}=D^{*} L_{\mathrm{i}} \\
& \mathrm{ESV}=\sum_{\mathrm{i}=1}^{\mathrm{n}}\left(S_{\mathrm{i}} * \mathrm{VC}_{\mathrm{i}}\right)
\end{aligned}
$$

\begin{tabular}{|c|c|c|c|c|c|c|c|c|c|c|c|}
\hline \multicolumn{2}{|c|}{ Classification of ecosystems } & \multicolumn{3}{|c|}{ Supply services } & \multicolumn{4}{|c|}{ Regulation services } & \multicolumn{2}{|c|}{ Composite services } & \multirow{2}{*}{$\frac{\text { Cultural services }}{\mathrm{AL}}$} \\
\hline Primary classification & Secondary classification & FP & $\mathrm{RP}$ & WS & GR & $\mathrm{CR}$ & ED & HA & $\mathrm{SC}$ & $\mathrm{BO}$ & \\
\hline \multirow[t]{2}{*}{ Farm land } & Dryland & 0.85 & 0.4 & 0.02 & 0.67 & 0.36 & 0.1 & 0.27 & 1.03 & 0.13 & 0.06 \\
\hline & Paddy land & 1.36 & 0.09 & -2.63 & 1.11 & 0.57 & 0.17 & 2.72 & 0.01 & 0.21 & 0.09 \\
\hline Forest land & Broad-leaved forest & 0.29 & 0.66 & 0.34 & 2.17 & 6.5 & 1.93 & 4.74 & 2.65 & 2.41 & 1.06 \\
\hline \multirow[t]{2}{*}{ Grass land } & Shrub forest & 0.19 & 0.43 & 0.22 & 1.41 & 4.23 & 1.28 & 3.35 & 1.72 & 1.57 & 0.69 \\
\hline & Brush grass & 0.38 & 0.56 & 0.31 & 1.97 & 5.21 & 1.72 & 3.82 & 2.4 & 2.18 & 0.96 \\
\hline Wet land & Wetland & 0.51 & 0.5 & 2.59 & 1.9 & 3.6 & 3.6 & 24.23 & 2.31 & 7.87 & 4.73 \\
\hline \multirow[t]{2}{*}{ Desert } & Wilderness & 0.01 & 0.03 & 0.02 & 0.11 & 0.1 & 0.31 & 0.21 & 0.13 & 0.12 & 0.05 \\
\hline & Bare land & 0 & 0 & 0 & 0.02 & 0 & 0.1 & 0.03 & 0.02 & 0.02 & 0.01 \\
\hline Water & Water bodies & 0.8 & 0.23 & 8.29 & 0.77 & 2.29 & 5.55 & 102.24 & 0.93 & 2.55 & 1.89 \\
\hline
\end{tabular}

Table 2 Ecosystem service equivalent value per unit area 
Table 3 Modified service equivalent values in the basin (yuan/ha)

\begin{tabular}{lllll}
\hline Equivalent factor & China & Hubei & Henan & Shaanxi \\
\hline 1990 & 35,674 & 43,174 & 23,144 & 19,984 \\
1995 & 38,324 & 46,788 & 25,908 & 18,425 \\
2000 & 40,480 & 50,708 & 43,151 & 22,712 \\
2005 & 44,910 & 51,784 & 48,431 & 25,106 \\
2015 & 53,046 & 58,563 & 57,171 & 38,618 \\
\hline
\end{tabular}

$\mathrm{VC}_{\mathrm{i}}$ is the service value per unit area for a given land use type (yuan/ha), $D_{\mathrm{i}}$ is the equivalent factor per unit area, and $L_{\mathrm{i}}$ is the ecosystem service equivalent value per unit area for a given land use type. ESV is the total value of ecosystem services, and $S_{\mathrm{i}}$ is the area of a given land use type (ha) in the research area.

\section{Methods for determining trade-offs and synergies}

Correlation analysis is a method used to study whether there are certain dependency relationships among phenomena and to explore the dependencies and degrees of correlation among the phenomena. It is a statistical method used to study the relationships between random variables (Brian 2000). The measure of this correlation is called the correlation coefficient. The correlation relationship has strong and weak directions, and higher values indicate stronger correlations. The formula for calculating the correlation coefficient is

$$
R_{\mathrm{xy}}=\frac{\sum_{i=1}^{n}\left(x_{\mathrm{i}}-\bar{x}\right)(y-\bar{y})}{\sqrt{\sum_{i=1}^{n}\left(x_{\mathrm{i}}-\bar{x}\right)^{2}} \sqrt{\sum_{i=1}^{n}\left(y_{\mathrm{i}}-\bar{y}\right)^{2}}} .
$$

$R_{\mathrm{xy}}$ is the correlation coefficient; $n$ is the number of samples; $x_{\mathrm{i}}$ and $y_{\mathrm{i}}$ are the ith values of $x$ and $y$, respectively; and $\bar{x}$ and $\bar{y}$ are the averages of the variables $x$ and $y$, respectively.

In this study, we analyzed the relationships among the ecosystem services of the whole basin and of the areas upstream and downstream of the Danjiangkou dam based on the estimated values of the ecosystem services. Negative values indicate that trade-offs exist, i.e., that the provision of one ecosystem service is reduced as a consequence of the increased use of another ecosystem service. Positive values indicate that synergies exist, i.e., that the provision of one ecosystem service is increased as a consequence of the increased use of another ecosystem service.

\section{Results}

\section{Changes in ecosystem services in the Hanjing River Basin}

\section{Temporal changes}

The ecosystem service value of the whole basin was then obtained using the provinces' ecosystem service values (Table 4):

From 1990 to 2015, the value of ecosystem services in the whole basin increased markedly, from 781.18 billion yuan to 1312.19 billion yuan. The total value of ecosystem services increased by 53.91 billion yuan, or $67.98 \%$, and annually by 2.124 billion yuan. During that 15 -year period, the years from 1995 to 2000 witnessed the fastest growth, followed by the years from 2010 to 2015, whereas the years from 1990 to 1995 witnessed the slowest growth.

Forests had the highest ecosystem service value, accounting for approximately $52 \%$ of the total ecosystem service value. In 1990 and 2015, the values of forest ecosystem services were 40,989 million yuan and 65,596 billion yuan, respectively, which was an increase of $60.03 \%$. The value of grassland ecosystem services ranked second and accounted for approximately $24 \%$ of the total ecosystem service value. In 1990 and 2015, the values of the forest ecosystem services were 20,071 million yuan and 341.55 billion yuan, respectively, an increase of $70.18 \%$. The ecosystem service value of water accounted for approximately $22-24 \%$ of the total ecosystem service value. In 1990 and 2015, the values of ecosystem services were 17,534 million yuan and 30,907 billion yuan, respectively, an increase of $76.26 \%$. The ecosystem service value of farmland accounted for approximately $8 \%$ of the total ecosystem service value. In 1990 and 2015, the ecosystem service values were 6518 million yuan and 10,745 billion yuan, respectively, an increase of $64.85 \%$. Wetlands, bare lands, and construction lands had low ecosystem service values. In past years, the values of these ecosystem services were less than 150 million yuan. In addition to wetlands, the ecosystem service values of the various land use types increased from 1990 to 2015.

Figure 2 shows the changes in values of the four major ecosystem service types in the whole basin from 1990 to 2015, which were obtained by adding the corresponding sub-ecosystem service values in Table 4 . The dominant ecosystem services were regulation services, which accounted for approximately $70 \%$ of the total ecosystem service value. The second-ranking value was that of support services, which accounted for approximately $17 \%$ of the total ecosystem service value. Supply services accounted for approximately $6 \%$ of the total ecosystem service value. The lowest-ranking value was that of cultural services, which accounted for only $3.7 \%$ of the total ecosystem service value. 
Table 4 Ecosystem service values in the entire basin (100 million yuan)

\begin{tabular}{llllllll}
\hline Year & & 1990 & 1995 & 2000 & 2005 & 2010 & 2015 \\
\hline Supply services & Food Production & 26.75 & 27.90 & 33.74 & 35.67 & 38.34 & 43.70 \\
& Raw Production & 20.67 & 21.49 & 25.96 & 27.65 & 29.77 & 34.69 \\
& Water Supply & 2.57 & 3.21 & 5.26 & 7.21 & 8.29 & 9.34 \\
Regulation services & Gas Regulation & 67.49 & 70.10 & 83.26 & 88.47 & 95.05 & 111.46 \\
& Climate Regulation & 162.00 & 168.48 & 198.70 & 211.59 & 227.35 & 268.45 \\
& Hydrological & 56.28 & 58.85 & 69.54 & 97.28 & 80.30 & 94.14 \\
& $\quad$ Adjustment & & & & & & \\
& Environment & 275.95 & 296.17 & 349.81 & 381.70 & 413.10 & 467.60 \\
Composite services & Depuration & & & & & & \\
& Soil Conservation & 75.65 & 78.50 & 94.31 & 100.60 & 108.26 & 127.14 \\
Cultural services & Biodiversity & 64.45 & 66.76 & 78.79 & 84.14 & 90.46 & 106.77 \\
Total & Aesthetic Landscape & 29.38 & 30.60 & 36.95 & 38.65 & 41.57 & 48.90 \\
Change from the previous period (\%) & - & 5.23 & 18.77 & 9.90 & 5.55 & 15.87 \\
\hline
\end{tabular}

\section{Spatial changes}

Figure 3 shows various ecosystem service values from 1990 to 2015 upstream and downstream of the Danjiangkou dam.

The ecosystem service values showed different increasing trends upstream and downstream of the Danjiangkou dam from 1990 to 2015. The ecosystem service values increased from 42.941 billion yuan to 74.881 billion yuan upstream of the dam and increased from 35.177 billion yuan to 56.339 billion yuan downstream of the dam. Overall, the ecosystem service values upstream and downstream of the dam increased year by year. Among the services, adjustments in food production and hydrological regulation downstream of the dam were approximately 1.5 times greater than those upstream. The remaining ecosystem service values upstream of the dam were approximately one to two times greater than those downstream. From the perspective of unit area, the ecosystem service value per unit area in the area upstream of the dam increased from 4511 million yuan/ha to 7866 million yuan/ha, whereas the ecosystem service value per unit area downstream of the dam increased from 5513 million yuan/ha to 8813 million yuan/ha. Adjustments in food production and hydrological values per unit area downstream of the dam were approximately two times greater than those upstream. The remaining ecosystem service values were roughly the same upstream and downstream of the dam.

Although the values of ecosystem services increased year by year, the dominant role of regulation services in ecosystem services has not changed. Therefore, we analyzed the advantages and disadvantages of ecosystem services using average

100Million RMB

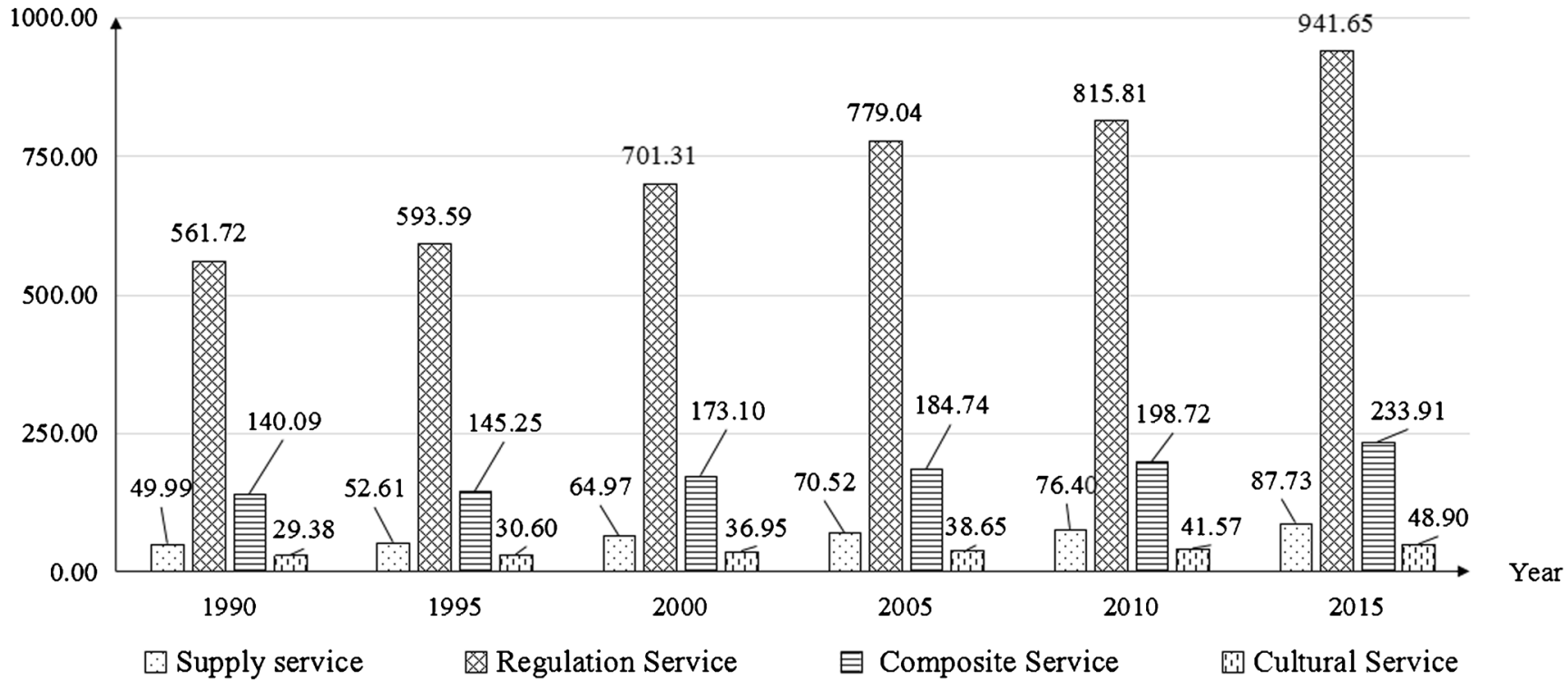

Fig. 2 Ecosystem service values during the period of 1990-2015 
Ecosystem service value

100 Million yuan

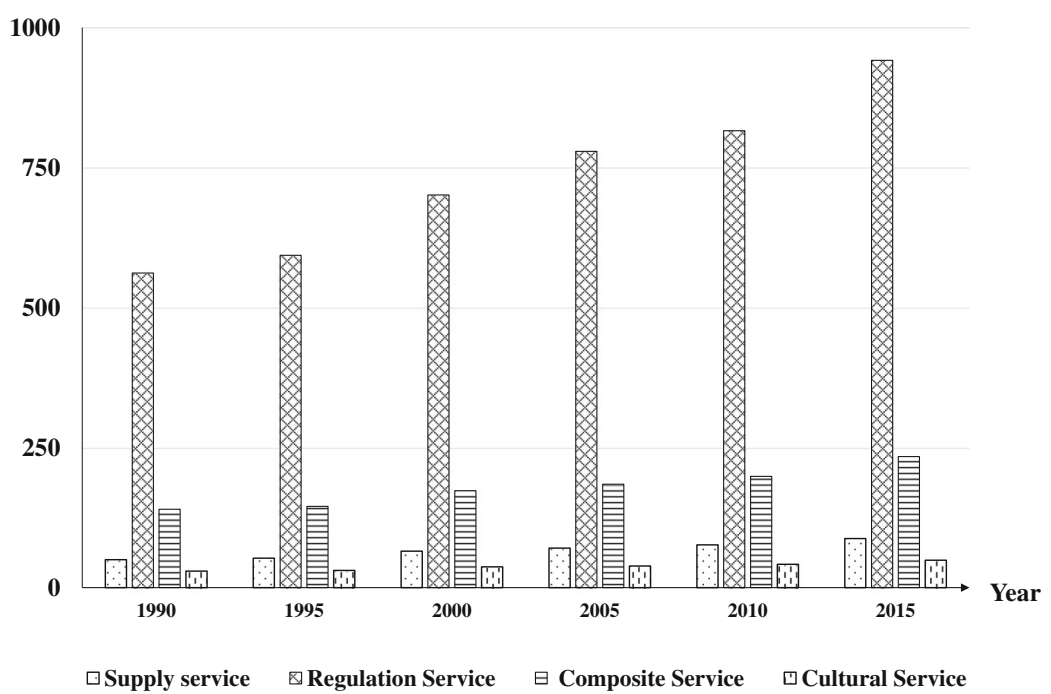

Fig. 3 Ecosystem service values from 1990 to 2015 upstream (Up) and downstream (Down) of the dam

values. Radar maps have advantages in terms of integrity, clarity, and intuition. They are often used in comprehensive analyses of many indicators. To analyze the differences between the different ecosystem services upstream and downstream of the dam, radar maps of 10 ecosystem services on either side of the dam were drawn based on the annual average values of the 10 ecosystem service values from 1990 to 2015 (Figs. 4 and 5). The dominant ecosystem services were hydrological adjustment and climate regulation. The radar maps are shown as two parts. The values of food production and environmental depuration were lower than those of the other ecosystem services. The radar map of ecosystem service values upstream of the dam had the shape of an inverted hook. The values of the other ecosystem services were lower, except for that of hydrological adjustment in regulation services.

\section{Relationships among ecosystem services in the whole basin}

Correlation analyses can be used to help determine the relationships among ecosystem services. In this study, these relationships were depicted graphically based on the estimated ecosystem service values in the whole basin during different periods. Figure 6 shows the correlations among ecosystem services in the whole basin, in the areas upstream and downstream of the dam separately, and in the combined areas
Fig. 4 Interactions between ecosystem services upstream of the dam

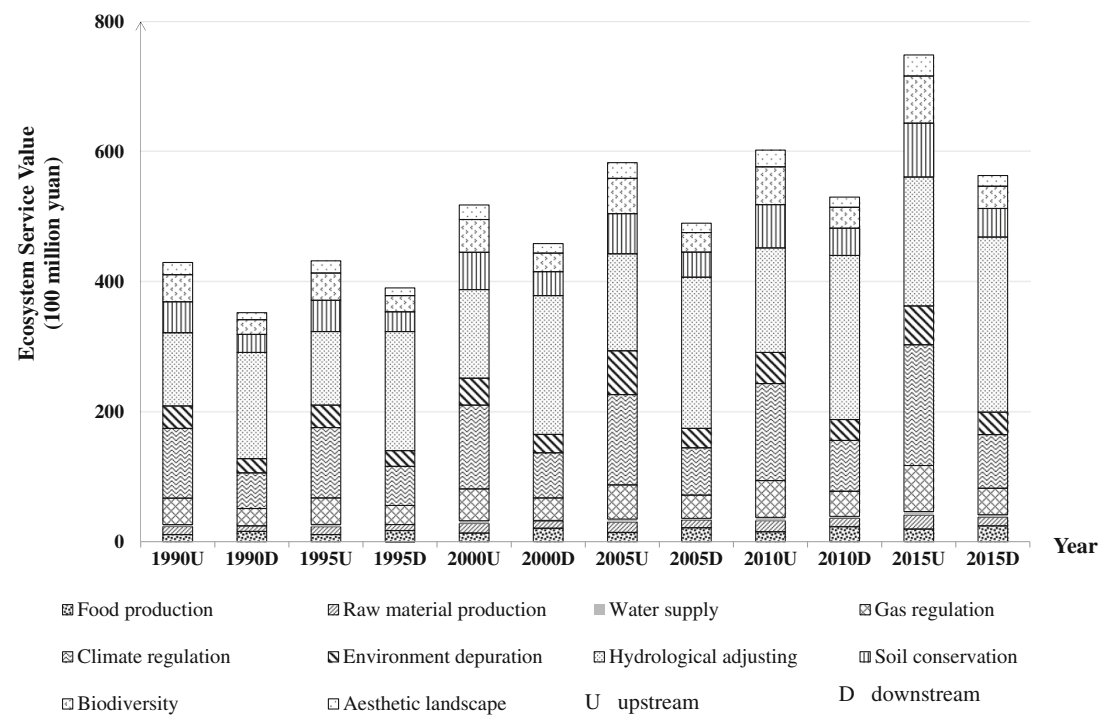


Fig. 5 Interactions between ecosystem services downstream of the dam

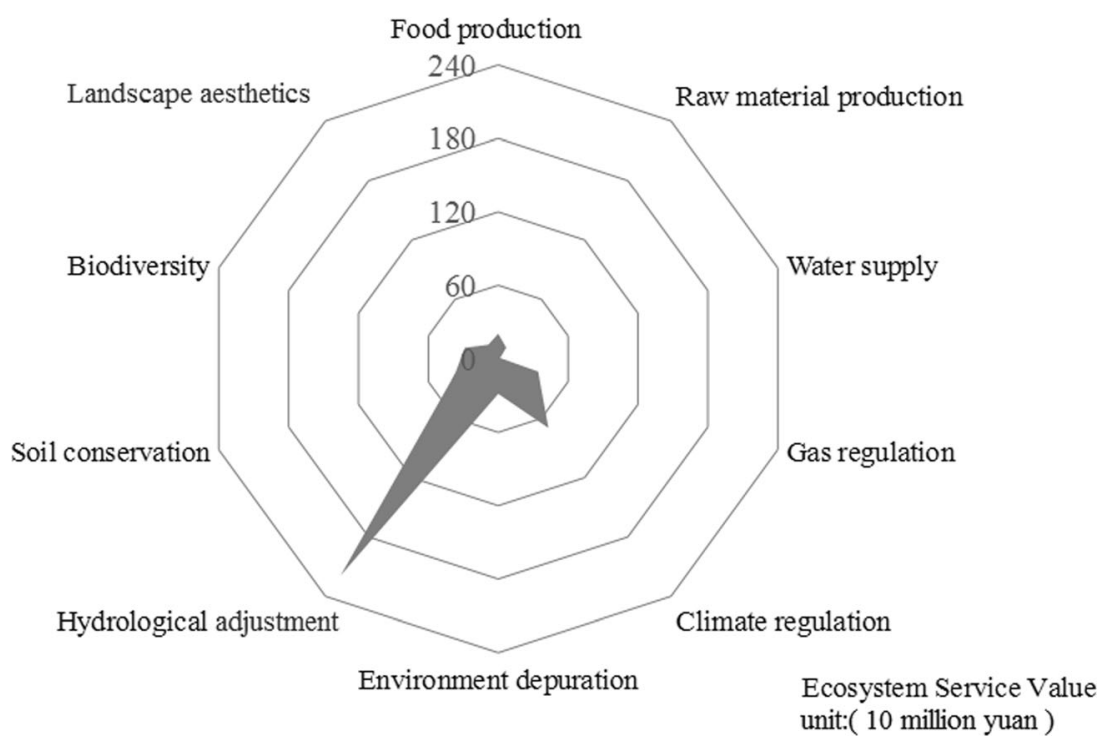

upstream and downstream of the dam. The dotted lines denote whether the relationship between the two ecosystem services was significant at levels of $P<0.01$ and $P<0.05$.

\section{Relationships among ecosystem services in the whole basin}

Synergistic relationship is the dominate relationship among ecosystem services in Hanjiang River Basin, accounting for $61 \%$. Synergy mainly exists in regulation services and support service. Trade-offs mainly exist in food production and other types of ecosystem services. The details are as follows:

There was a synergistic relationship between food production and raw material production in supply services, and this correlation was positive. However, both food production and raw material production had negative correlations with cultural services and regulation services (in particular, these services showed a significant negative correlation with regulation services, and this correlation coefficient was -0.837 ). The former two services increased as the latter two decreased, indicating significant trade-off relationships.

Raw material production and food production presented positive correlations with composite services, showing a synergistic relationship. In contrast, water supply in support services showed a positive correlation with cultural services and regulation services (in particular, water supply showed a significant positive correlation with regulation services, and this correlation coefficient was 0.984 ). In addition, water supply showed a negative correlation with composite services.

Gas regulation and climate regulation, and environment depuration and hydrological adjustment were significantly correlated. Gas regulation and climate regulation showed a positive correlation with food production and raw material production. In addition, gas regulation and climate regulation showed a negative correlation with water supply. Both had a significant positive correlation with composite services, and this correlation coefficient was 0.93 . In contrast, environment depuration and hydrological adjustment had a negative correlation with food production and raw material production. They showed a significant positive correlation with water supply. They had a negative correlation with composite services, and this correlation coefficient was -0.26 . However, these four regulation services had a positive correlation with cultural services and presented a trend in coordinated growth.

Soil conservation had a significant positive correlation with raw material production, gas regulation, and climate regulation. In addition to food production, biodiversity had a positive correlation with other types of ecosystem services. In addition, biodiversity had a significant positive correlation with cultural services.

Cultural services had a negative correlation with food production and raw material production. Both food production and raw material production had positive correlations with regulation services, composite services, and water supply; these correlation coefficients were $0.649,0.711$, and 0.484 , respectively.

\section{Spatial differences in the relationships among ecosystem services}

Synergistic relationship is the dominate relationship among ecosystem services in both upstream and downstream of the dam, accounting for $66 \%$ and $53 \%$. In upstream of the dam, food production showed trade-offs with regulation services, composite services, and cultural services. In addition, water supply and hydrological adjustment also showed trade-offs with composite services and regulation services. In upstream of the dam, food production showed trade-offs with regulation services, composite services, and cultural services. The details are as follows: 
Fig. 6 Relationships among ecosystem services in the whole basin, upstream of the dam, downstream of the dam, and the combination of the areas upstream and downstream of the dam

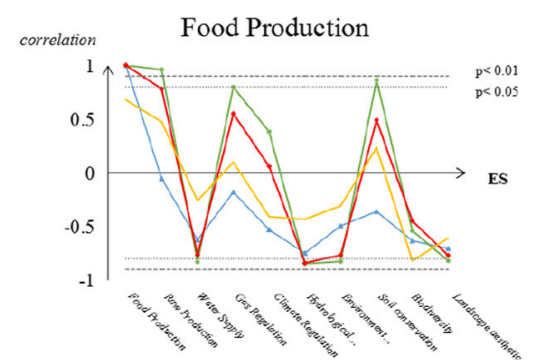

correlation Raw material production
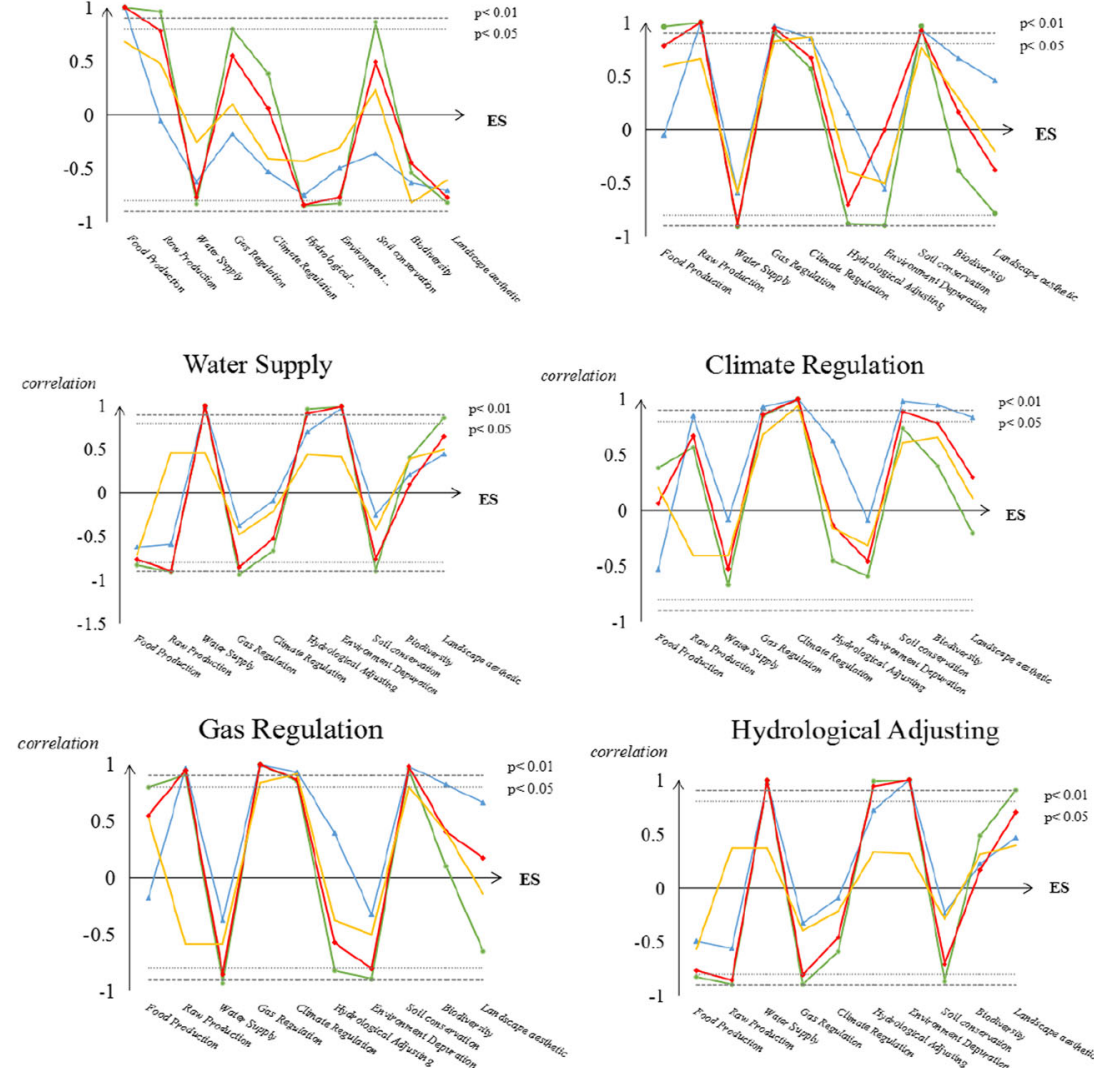

correlation Hydrological Adjusting

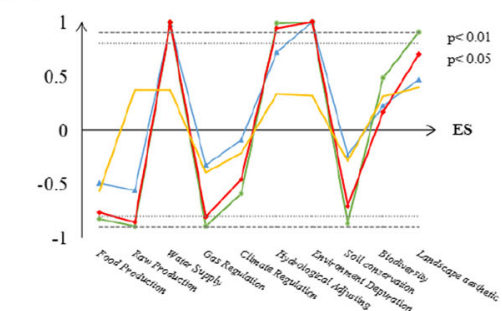

correlatio

Environment Depuration

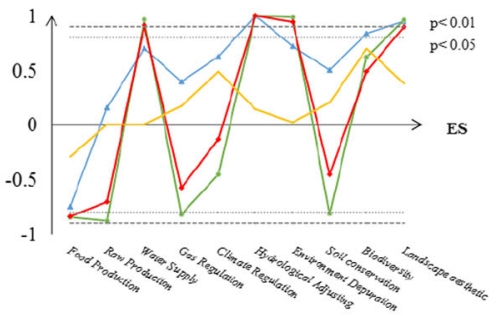

correlation

Soil Conservation
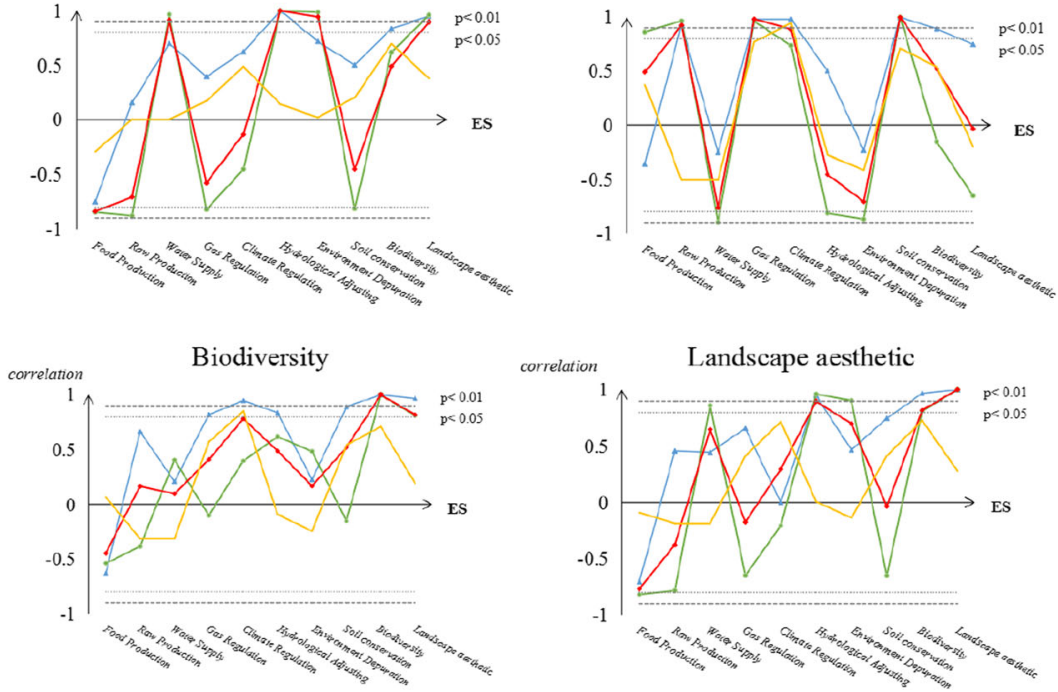

correlation Landscape aesthetic

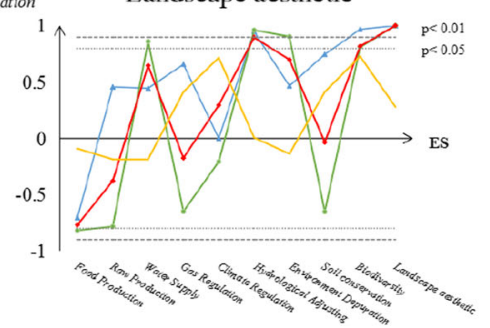

Upstream and downstream - $\quad \mathrm{p}<0.05 \cdots \mathrm{p}<0.01$
Among the support services, food production showed trade-offs with raw material production, gas regulation, climate regulation, and soil conservation upstream of the dam. However, these relationships turned into synergies downstream of the dam. In addition, they had significant positive correlations with raw material production and soil conservation. Raw material production showed synergistic relationships with environment depuration, biodiversity, and landscape aesthetics upstream of the dam. These relationships turned into trade-offs downstream of the dam, where there was a significant negative correlation with environment depuration. 
Among the regulation services, soil conservation performed differently upstream versus downstream of the dam. Upstream of the dam, soil conservation showed significant synergies with biodiversity, whereas this relationship turned into a trade-off downstream of the dam.

In general, ecosystem services more often showed synergies upstream than downstream of the dam. In addition, the synergies upstream of the dam mostly corresponded to regulation, composite, and cultural services. Trade-offs were relatively common downstream of the dam, and most of these tradeoffs corresponded to supply services and regulation services.

\section{Relationships upstream and downstream of the dam}

Synergistic relationship is the dominate relationship among the ecosystem services upstream and downstream of the dam, accounting for $59 \%$. Food production upstream of the dam shows a significant negative correlation with biodiversity downstream of the dam. Climate regulation upstream of the dam shows a significant positive correlation with climate regulation downstream of the dam. Raw material production, gas regulation, climate regulation, soil conservation, and biodiversity upstream of the dam showed significant positive correlations with gas regulation and climate regulation downstream of the dam.

The increase in ecosystem value upstream of the dam will have a positive impact on gas regulation and climate regulation downstream of the dam. In addition, the increase in upstream food production can cause serious negative effects on biodiversity downstream of the dam.

\section{Discussion}

\section{Changes in ecosystem service values and their driving factors}

The total ecosystem service value (1990-2015) of the whole basin increased year by year, and the largest annual increases occurred in the 1995-2000 period, followed by those in the 2000-2015 period. Forest ecosystem services provided the highest value. Regulation services played the dominant role. The distributions of ecosystem service values upstream of the Danjiangkou dam were higher than those downstream. In 1990-2015, ecosystem service in the upstream of the dam increased from 42.941 billion yuan to 74.881 billion yuan. The increase was $74.36 \%$. Ecosystem service in the upstream of the dam increased from 35.177 billion yuan to 56.339 billion yuan. The increase was $60.04 \%$. In addition to food production and hydrological adjustment, the ecosystem service values upstream of the dam were approximately one to two times greater than those downstream of the dam.
Explanations for these patterns are as follows. First, the annual increase in equivalent factors led to year-by-year increases in the ecosystem service value. Second, human activities led to the changes in land use. These changes finally led to the changes in ecosystem services. In recent years, with economic development throughout the basin, people have paid increased attention to the importance of the local ecology. Therefore, more measures have been undertaken to control environmental pollution. With the implementation of the South to North Water Transfer Project, efforts were made to ensure that water quality policies such as those affecting reforestation, water pollution control, and soil and water conservation planning (Zhou et al. 2015) were vigorously enforced. Implementation of those policies has controlled water pollution, non-point source pollution, agricultural and livestock breeding pollution, and soil erosion throughout the basin, and as a result, the ecosystem service value of the whole basin has increased year by year. Although the project's implementation enhanced certain ecosystem service values in the study area, it changed ecological conditions upstream and downstream of the dam to a certain extent. In particular, after the commencement of the Danjiangkou Dam Raising Project, the increase in surface water area upstream was accompanied by a related increase in ecosystem service value. The ecosystem service values for water supply, environment depuration, and hydrological adjustment are increased by $35.51 \%, 44.62 \%$, and $45.52 \%$. Research has shown that implementation of the South to North Water Transfer Project and the Danjiangkou dam had a significant negative impacts on the downstream ecological environment, including the water supply, soil texture, and biodiversity (Gao and Gao 2010), which was also one of the important factors that caused the ecosystem service value in the lower part of the basin to be far less than that upstream of the dam. Third, the condition of the natural ecosystem is closely related to the value of the service function provided by the ecosystem per unit area. There are large areas consisting of forest and grassland upstream of the dam, and these areas account for approximately $48 \%$ of the total area. Downstream of the dam, agriculture is the main land use and accounts for $50 \%$ of the total area. The total ecosystem service value downstream of the dam was lower than that upstream of the dam, whereas the service value of food production downstream of the dam was slightly higher than that upstream of the dam.

\section{Analysis of trade-offs}

There are various types of landforms in the basin, including mountains, plains, and hills. The corresponding ecosystems interact with and restrict one another, forming unique ecological relationships in this region. From the study of trade-offs and synergies among the ecosystem services at different levels in the whole basin, we found that the trade-offs between 
ecosystems differed in different regions due to the dissimilar demands placed on ecosystem services.

\section{Explanations of trade-offs and synergies in the whole basin}

The analysis revealed the trade-offs between food production, raw material production in supply services, and regulation services and cultural services throughout the basin. In addition, this study revealed the synergies between food production and raw material production in supply and composite services. The explanation is that the capacities of regulation and cultural ecosystem services in forest and grassland areas are strong, whereas those of food and raw material production are weak. Agricultural land greatly enhanced the capacity to food and raw material production. However, soil erosion was severe on agricultural lands due to improper farming practices (Li et al. 2003; Yang et al. 2015). This erosion weakened the effects of regulation on agricultural lands. However, food production showed synergies between gas regulation and climate regulation, as did raw material production and gas and climate regulation. Although the adjustment capacities of these two ecosystem services differed from those of agricultural lands (especially paddy fields), forests, grasslands, and water, the differences were far less than the difference in environment depuration and hydrological adjustment. The land area devoted to agriculture in the basin is large, and $67 \%$ of this agricultural land consists of rice paddies. The relationships between water supply and regulation services, composite services, and cultural services were the opposite of the relationship between food production and raw material production. This contrast existed because the service value of the water supply derives primarily from water, whereas agriculture land (especially paddies), with its strong effect on food production, places a high demand on water for irrigation. Therefore, paddy fields, with their high capacities for food production and raw material production, correlate with lower water supplies. Surface water areas, with their strong associations with regulation services and cultural services, are associated with higher water supply capacities.

Among the regulation services, the relationships between composite services and gas regulation and climate regulation were the opposite of those between composite services and environment depuration and hydrological adjustment. This pattern existed because water plays an important role in environment depuration and hydrological adjustment (such as the ecosystem service value per unit area of hydrological adjustment, which reached 12,424 yuan/ha-much larger than the equivalent value of other land use types) but was not prominent in gas regulation and climate regulation. Therefore, water areas and their low capacities for composite services have higher capacities for environment depuration and hydrological adjustment. Agriculture lands and forests with high capacities for composite services have higher capacities for environment depuration and hydrological adjustment. However, these four types of services are synergistic with cultural services. The explanation for this pattern is that forests and water areas with high capacities for regulation services provide large amounts of carbon storage. In addition, they play an important role in climate regulation (Wang et al. 2007), which greatly contributed to the increase in biological species and landscape aesthetic values in this region. Composite services are synergistic with cultural services because forests and grasslands with high capacities for soil conservation and biodiversity also have high capacities for landscape aesthetics.

\section{Analysis of trade-offs and synergies among ecosystem services upstream and downstream of the dam}

Based on the findings regarding trade-offs and synergies in the whole basin, we found that trade-offs and synergies downstream of the dam were more significant than those upstream of the dam, which was due to the spatial differences between the land uses on either side of the dam. Specifically, forests and grasslands, which are the main land uses upstream of the dam, have high levels of adjustment ability and high aesthetic values. Due to the lesser amount of agricultural land, the ecosystem service value is low. In contrast, the main land use downstream of the dam is agriculture, and the ecosystem service value of the agricultural land is high and accounts for a larger proportion of all ecosystem service values. In addition, the adjustment and cultural services downstream of the dam are not as great as those upstream. Upstream raw material production, gas regulation, climate regulation, soil conservation, and biodiversity have significant synergies with downstream gas regulation and climate regulation. In addition, there are significant trade-offs between upstream food production and downstream biodiversity.

In summary, hydrological adjustment plays a leading role in the whole basin and is of great significance to the sustainable growth of the ecosystem services. The implementation of the South to North Water Transfer Project has solved the problem of water demand in the north and made important contributions to social and economic development. At the same time, the project also adversely affects the ecological environment in the basin (Zhou et al. 2015). Upstream of the dam, the raising of the dam has substantially increased the value of ecosystem services such as water supply and hydrological adjustment. However, the increase in surface water area caused the decrease in agricultural land area. At the same time, with the rapid economic development, the area upstream of the dam is facing dual pressures of population growth and urbanization. To grow more food, forests and grasslands are inevitably destroyed (David et al. 2016). In addition, poor farming practices will also worsen soil erosion upstream of the dam and will thus affect gas regulation, biodiversity, and other ecosystem services (DeFries et al. 2016). Changes to 
upstream ecosystem services such as gas regulation also have a negative impact on biodiversity and climate regulation below the dam, thereby worsening the ecological environment throughout the basin. The water quality below the dam was significantly harmed after the implementation of the Middle Route of the South to North Water Transfer Project (Fan and Liu 2016). With the decrease in water volume, the area of sand lands will further expand (Zhang and Xie 2014), causing the vegetated areas in wetlands and along riverbanks to decrease and weaken climate regulation. Hydrological characteristics and environments that are closely related to aquatic organisms, including flow, velocity, water temperature, and sediment concentration, changed after the project was completed (Zeng 2008). In addition, the raising of the dam further blocked the migration and exchange of aquatic organisms, and food chain biodiversity was also affected (Fan et al. 2017), which resulted in the inability of ecological cycles to function properly (Guan et al. 2016a).

\section{Impact of dam construction on ecosystem services and relationships}

The study found that there are differences in different types of ecosystem services between upstream and downstream of the dam. The dam locks the water originally belonging to the river channel in the reservoir area, so the water supply and hydrological adjustment in the downstream of the dam is lower than the upstream due to the decrease of incoming water. The increase in the area of the reservoir area will inevitably flood the surrounding farmland, resulting in the impaction of food supply, gas regulation, and climate regulation of the reservoir area. In addition, considering the water resources security in the reservoir area, the ecological environment protection in the upstream of the dam is better than the downstream of the dam. Different development purposes make the development direction of the social economy different, and different development directions cause the different land use. Therefore, the ecosystem service value in the upstream of the dam is higher than the downstream of the dam, and the synergy in the upstream is more common than the downstream of the dam.

\section{Suggestions regarding protection of ecological systems throughout the basin under the influence of the Danjiangkou dam}

To ensure the stability of the ecological system and smooth operation of the Middle Route of the South to North Water Transfer Project and achieve a win-win outcome between the north and south, ecological engineering measures and land management should be vigorously promoted by relevant departments in the whole basin. In addition to directly mitigating soil erosion, agricultural pollution, biodiversity degradation, and other ecological problems, increased attention should be paid to the links among ecosystems. In addition, corresponding ecological problems can be solved indirectly through the links and restrictions among ecosystem services. We found that gas regulation and climate regulation upstream of the dam not only have a synergistic effect on support services and cultural services upstream of the dam but also have significant synergistic effects on gas regulation and climate regulation downstream of the dam. In addition, the enhancement of gas and climate regulation downstream of the dam will drive growth in support and composite services. Forests and grasslands have played a positive role in regulation services. Therefore, it is necessary to ensure the smooth implementation of the policy of returning farmlands to forests to promote the capacities of gas and climate regulation upstream of the dam, which is the foundation of future planning upstream. Meanwhile, projects such as "Grain for Green" and "delineation of the farmland protection red line" should be vigorously implemented to ensure food supplies. Advanced pollution prevention technology should be actively introduced to prevent agricultural non-point source pollution and the vicious cycle caused by the effects of soil erosion on the ecological system. We should accelerate the construction of compensation projects such as supporting canalization works in the middle and downstream regions of the dam, the Project of Water Diversion from the Yangtze River to the Hanjiang River, and the Dongjing River Water Supply Project (Liu et al. 2005a, b). A scientific ecological compensation mechanism should be established to minimize the negative impacts of water diversion. Natural reserves should be constructed to reduce negative effects of landscape fragmentation caused by the dam. Ecosystem connectivity should be strengthened to prevent watershed ecosystem services from being affected by regional water transfer projects (Maes et al. 2012).

\section{Conclusions}

Using the Danjiangkou dam as an example, we studied the trade-offs and synergies upstream and downstream of the dam under the influence of a water diversion project. First, ecosystem service values and their spatial distribution were estimated using the ecosystem service estimation method proposed by Costanza, which is based on land use data (Costanza et al. 1997). On that basis, ecosystem service values were revised considering the dynamic changes and differences in ecosystem services on temporal and spatial scales. Then, trade-offs and synergies among the ecosystem services in the basin were comprehensively analyzed from three aspects: the whole basin, upstream and downstream of the dam separately, and upstream and downstream of the dam together. The results led to the following conclusions: 
1. The ecosystem service value in the whole basin increased significantly from 1990 to 2015. Climate regulation and hydrological adjustment were the dominant services. Among the land uses, forests contributed the greatest ecosystem service value.

2. There are spatial differences between the ecosystem services upstream and downstream of the dam. The ecosystem service values upstream of the dam were higher than those below the dam. Hydrological adjustment and climate regulation were dominant. Ecosystem service values downstream of the dam were relatively low, with the exception of hydrological adjustment.

3. Synergies among ecosystem services in the whole basin accounted for $60 \%$ of the relationships and existed mainly between regulating services and composite services and cultural services. Trade-offs existed primarily between supply services and regulation services.

4. There were spatial differences in the relationships among ecosystem services between the regions upstream and downstream of the dam. There were more ecosystem services with synergies upstream of the dam, primarily between regulation services and composite services and cultural services. There were more ecosystem services with trade-offs downstream of the dam, primarily between regulation services and supply services.

5. There were eight groups of ecosystem services with significant relationships between the regions upstream and downstream of the dam. Among them, upstream food production and downstream biodiversity had significant trade-offs. Raw material production, gas regulation, climate regulation, soil conservation, and biodiversity upstream of the dam showed strong synergies with gas regulation and climate regulation downstream of the dam.

Funding information This study was supported by Special Fund by Surveying \& Mapping and Geo-information Research in the Public Interest (201512026) and the Science and Technology Program of Jiangxi Province, China (20171BBE50073).

Open Access This article is distributed under the terms of the Creative Commons Attribution 4.0 International License (http:// creativecommons.org/licenses/by/4.0/), which permits unrestricted use, distribution, and reproduction in any medium, provided you give appropriate credit to the original author(s) and the source, provide a link to the Creative Commons license, and indicate if changes were made.

\section{References}

Agarwala M, Atkinson G, Fry BP, Homewood K, Mourato S, Rowcliffe JM, Wallace G, Milner-Gulland EJ (2014) Assessing the relationship between human well-being and ecosystem services: a review of frameworks. Conserv Soc 12:437-449
Alcamo J, Detlef P, Ringler C, Schulze K (2005) Changes in nature's balance sheet: model-based estimates of future worldwide ecosystem services. Ecol Soc 10(2):19

Bohensky EL, Reyers B, Jaarsveld AS (2006) Future ecosystem services in a southern African river basin: a scenario planning approach to uncertainty. Conserv Biol 20(4):1051-1061

Bonacci O, Bonacci RT (2003) The influence of hydroelectrical development on the flow regime of the karstic river Cetina. Hydrol Process 17(1):1-15

Brian PO (2000) SPSS and SAS programs for determining the number of components using parallel analysis and Velicer's MAP test. Behav Res Methods Instrum Comput 32:396-402

Brown G, Fagerholm N (2015) Empirical ppgis/pgis mapping of ecosystem services: a review and evaluation. Ecosyst Serv 13:119-133

Byron C, Jin D, Dalton T (2015) An integrated ecologicaleconomic modeling framework for the sustainable management of oyster farming. Aquaculture 447:15-22

Cao QW, Wei XM, Wu JS (2016) A review on the tradeoffs and synergies among ecosystem services. Chin J Ecol 35(1):3102-3111

Chen XL, He X, Liu H (2015) Changs on eco-service value in central water source area of middle route of south-to-north water diversion project. J Central China Normal Univ (Nat Sci) 49(3):434-439

Chen SS, Liu K, Li T, Yuan JG (2016) Evaluation of ecological service function of soil conservation in Shangluo City based on InVEST model. Acta Pedol Sin 3:800-807

Chisholm RA (2010) Trade-offs between ecosystem services: water and carbon in a biodiversity hotspot. Ecol Econ 69:1973-1987

Cord AF, Bartkowski B, Beckmann M, Dittrich A, Hermans-Neumann K, Kaim A, Lienhoop N, Locher-Krause K, Priess J, SchröterSchlaack C, Schwarz N, Seppelt R, Strauch M, Václavík T, Volk M (2017) Towards systematic analyses of ecosystem service tradeoffs and synergies: main concepts, methods and the road ahead. Ecosyst Serv:1-9

Costanza R, Arge R, Groot RD, Farber S, Grasso M, Hannon B, Limburg K, Naeem S, O'Neill R, Paruelo J, Raskin RG, Sutton P, Belt M (1997) The value of the world's ecosystem services and natural capital. Nature 387:253-260

Daily GC (1997a) Societal dependence on natural ecosystems, N.s. services, Editor. Island Press, Washington DC

Daily GC (ed) (1997b) Preface. Nature's services: societal dependence on natural ecosystems. Island Press, Washington, D.C

Daily GC, Polasky S, Goldstein J, Kareiva PM, Mooney HA (2009) Ecosystem services in decision making: time to deliver. Front Ecol Environ 7(1):21-28

David RK, Mark M, Sylvia LR, Cheryl P, John A, Patricia B, Virginia HD, Petr H, Keith L, Kline RJ, Philip T, Pablo T, Sandy A (2016) Evaluating agricultural trade-offs in the age of sustainable development. Agric Syst 9:1-16

DeFries R, Mondal P, Singh D, Agrawal I, Fanzo J, Remans R, Wood S (2016) Synergies and trade-offs for sustainable agriculture: nutritional yields and climate-resilience for cereal crops in Central India. Glob Food Sec 11:44-53

Fan H, Liu JZ (2016) The Loss of Ecological Service Value after WetlandArea Decreasing in Middle and Lower Reaches of Hanjiang River. Wet Sci 4:576-579

Fan YL, Hu N, Ding SY (2017) The influence of dam on downstream landscape pattern and ecosystem services. Chin J Ecol 36(1):240-247

Farber S, Costanza R, Childers DL, Erickson J, Gross K (2006) Linking ecology and economics for ecosystem management. Bioscience 56(2):121-133

Gao YN, Gao JF (2010) Comprehensive assessment of eco-environment impact of the south-to-north water transfer middle route project on the middle-lower Hanjiang River Basin. Prog Geogr 29(1):60-64

Gao J, Li F, Gao S, Zhou CB, Zhang XL (2016) The impact of land-use change on water-related ecosystem services: a study of the Guishui River Basin, Beijing, China. J Clean Prod 1(49):2-8 
Guan XJ, Liu WK, Chen MY (2016a) Study on the ecological compensation standard for River Basin water environment based on Total pollutants control. Ecol Indic 69:446-452

Guan XJ, Liu WK, Chen MY (2016b) Study on the ecological compensation standard for River Basin water environment based on total pollutants control. Ecol Indic 69:446-452

Guy Z, Baranb E, Namc S, Rodríguez-Iturbed L, Simon A (2012) Levin.Trading-off fish biodiversity, food security, and hydropower in the Mekong River Basin. Proc Natl Acad Sci U S A 109(15): 5609-5614

Heina L, Koppen K, Rudolf S, Ekko C (2006) Spatial scales stakeholders and the valuation of ecosystem services. Ecol Econ 57(2):209-228

Higgins SI, Turpie JK, Costanza R, Cowling RM, Maitre DCL (1997) An ecological economic simulation model of mountain fynbos ecosystems: dynamics, valuation and management. Ecol Econ 56(2):155169

Hurford AP, Harou JJ (2014) Balancing ecosystem services with energy and food security - assessing trade-offs from reservoir operation and irrigation investments in Kenya's Tana Basin. Hydrol Earth Syst Sci 18:3259-3277

Hussain A, Tschirhart J (2013) Economic ecological tradeoffs among ecosystem services and biodiversity conservation. Ecol Econ 93: $116-127$

Kai X, Fan BK (2017) The analysis of farmers' willingness to accept and its influencing factors for ecological compensation of Poyang Lake wetland. Proc Eng 174:835-842

Kharrazi A, Akiyama T, Yu Y, Li J (2016) Evaluating the evolution of the Heihe River basin using the ecological network analysis: efficiency, resilience, and implications for water resource management policy. Sci Total Environ 572:688-696

Kremen C (2008) Managing ecosystem services: what do we need to know about their ecology? Ecol Lett 8(5):468-479

Langner A, Irauschek F, Perez S, Pardos M, Zlatanov T, Öhman K, Nordström E, Lexer M (2017) Value-based ecosystem service trade-offs in multi-objective management in European mountain forests. Ecosyst Serv 26:245-257

Li XM, Ao RJ, Liu RZ, Liu M, He BG, Chen LY, Chen GX (2003) Middle route project of south-north water transfer and ecological environment protection in Hanjiang Basin. J Central China Normal Univ(Nat Sci) 37(3):434-435

Li SC, Liu JL, Zhang CY (2011a) The research trends of ecosystem services and the paradigm in geography. Acta Geograph Sin 66(12):1618-1630

Li YQ, Deng O, Zhang DY, Han DL, Feng ZK (2011b) Land use and ecosystem service value scenarios simulation in Danjiangkou reservoir area. Trans CSAE 27(5):329-335

Li P, Jiang LG, Feng ZM, Yu XB (2012) Research progress on trade-offs and synergies of ecosystem services: an overview. Acta Ecol Sin 32(16):5219-5229

Li GP, Wang YQ, Zhang WB (2017) The influence of dam on downstream landscape pattern and ecosystem services. Chin J Ecol 36(1): 240-247

Liu BJ, Shao DJ, Xu MM, Yang SM (2005b) Analysis on the interactive effects between middle route of south to north water transfer project and the middle and lower basins of Hanjiang River. Resources and Environment in the Yang tze Basin 14(1):67-70

Liu JY, Qin KY, Zhou ZX, Yang XN, Li T (2017) Changes in land-uses and ecosystem services under multi-scenarios simulation. Sci Total Environ 586:522-526

MA (2005) Ecosystems and human well-being: our human planet: summary for decision makers[M]. Ecosystems and Human Well-Being: Island Press, Washington DC, pp 71-84
Lu CX, Xie GD,Cheng SK, Yu GR (2003) Approaches to evaluate the effects of hydraulic engineering on river ecosystem services.Chinese journal of applied ecology 14(5):803-807. https://doi.org/10.13287/ j.1001-9332.2003.0180

Maes J, Egoh B, Willemen L, Liquete C, Vihervaara P, Schägner JP, Grizzetti B, Drakou E, Notte A, Zulian G, Bouraoui F, Paracchini ML, Braat L, Bidoglio G (2012) Mapping ecosystem services for policy support and decision making in the European Union. Ecosyst Serv 1(1):31-39

Posnera S, Verutesc G, Koha I (2016) Cover image global use of ecosystem service models, ecosystem. Services 17(2):131-141

Raudsepphearne C, Peterson GD, Bennett EM (2010) Ecosystem service bundles for analyzing tradeoffs in diverse landscapes. Proc Natl Acad Sci U S A 107(11):5242-5247

Rodríguez JP, Beard TD, Bennett EM, Cumming GS (2006) Trade-offs across space, time, and ecosystem services. Ecol Soc 11(1):709-723

Sandifer PA, Sutton-Grier AE, Ward BP (2015) Exploring connections among nature, biodiversity, ecosystem services, and human health and well-being: opportunities to enhance health and biodiversity conservation. Ecosyst Serv 12:1-15

Schlüter M, Leslie H, Levin S (2009) Managing water-use trade-offs in a semi-arid river delta to sustain multiple ecosystem services: a modeling approach. Ecol Res 24(3):491-503

Schmalz B, Kruse M, Kiesel J, Müller F, Fohrer N (2016) Water-related ecosystem services in Western Siberian lowland basins - analysing and mapping spatial and seasonal effects on regulating services based on ecohydrological modelling results. Ecol Indic 71:55-56

Sun X, Li F (2017) Spatiotemporal assessment and trade-offs of multiple ecosystem services based on land use changes in Zengcheng, China. Sci Total Environ 609:1569-1581

Sutherland WJ, Armstrong-Brown S, Armsworth PR, Tom B, Brickland J, Campbell CD (2006) The identification of 100 ecological questions of high policy relevance in the UK. J Appl Ecol 43(4):617-627

Trodahl MI, Jackson BM, Deslippe JR, Metherell AK (2017) Investigating trade-offs between water quality and agricultural productivity using the land utilisation and capability indicator (luci) - a New Zealand application. Ecosyst Serv 26:388-399

Villasante S, Lopes PFM, Coll M (2015) The role of marine ecosystem services for human well-being: disentangling synergies and tradeoffs at multiple scales. Ecosyst Serv 16(1-4)

Wang JS, Li WH, Reng QS (2007) The value of Tibet's forest ecosystem services. J Nat Resour 22(5):831-841

WCD (World Commission on Dams) (2000) Dams and development: a new framework for decision-making. Earthscan Publications, London

Wilson CL, Matthews WH (1970) Man's Impact on the Global Environment, Study of Critical Environmental Problems (SCEP). Massachussetts, MIT Press, Cambridge

Worm B, Barbier EB, Beaumont N, Duffy JE, Folke C, Halpern BS, Jackson JB, Lotze HK, Micheli F, Palumbi SR, Sala E, Selkoe KA, Stachowicz JJ, Watson R (2006) Impacts of biodiversity loss on ocean ecosystem services. Science 314(5800):787-790

Xie GD, Lu CX, Leng YF (2003) Ecological assets valuation of the Tibetan Plateau. J Nat Resour 18(2):189-196

Xie GD, Zhen L, Lu CX (2008) Expert knowledge based valuation method of ecosystem services in China. J Nat Resour 23(5):911-919

Xie GD, Cao SY, Xiao Y (2015a) Ecosystem service evaluation. Contemporary Ecology Research in China, press springer 10:133177

Xie GD, Zhang CX, Chen WH, Li SM (2015b) Improvement of the evaluation method for ecosystem service value based on per unit area. J Nat Resour 30(8):1244-1254 
Yang XNL, Qin KY, Liu T, Liu JY (2015) Trade-offs between ecosystem services in Guanzhong-Tianshui economic region. Acta Geograph Sin 70(11):1762-1773

Zeng Q (2008) Analysis of water environment changes and causes in the middle and lower reaches of the Hanjing River Basin. Resour Environ Dev 1:9-13

Zhang L, Xie YY (2014) Study on the ecological service function of soil and water conservation in the south-to-north water diversion project. Soil Water Conserv China 4:46-49
Zhang L, Wi YH, Fu BJ (2017) Mapping ecosystem services for China's ecoregions with a biophysical surrogate approach. Landsc Urban Plan 161:22-31

Zhao SD, Zhang YM (2006) Ecosystems and human well-being: the achievements, contributions and prospects of the millennium ecosystem assessment. Adv Earth Science 21(9):896-902

Zhou C, Ding XH, Li GP, Wang HZ (2015) Ecological compensation standards in the water source area of the middle route project of the south-north water transfer project. Resour Sci 37(4):792-804 